\title{
Tropoelastin Gene Expression in the Rat Pulmonary Vasculature: A Developmental Study
}

\author{
AKIHHIKO NOGUCHI, HEND SAMAHA, AND DAPHNE E. DEMELLO \\ Department of Pediatrics [A.N., H.S.] and Department of Pathology [D.E.d.M.], Cardinal Glennon Children's \\ Hospital, Pediatric Research Institute, St. Louis University, School of Medicine, St. Louis, Missouri 63104
}

\begin{abstract}
The elastic laminae in a vessel provide resilience to its wall. In perinatal and adult rats, we used in situ hybridization to localize the mRNA for tropoelastin (TE) in endothelial cells, medial smooth muscle cells, and adventitial fibroblasts of pulmonary arteries and veins to determine the contribution of these cells to laminae formation. We found that 1 ) all three cell types are elastogenic but for each the ontogenic pattern is different, 2) signal in the artery is strongest in the late fetal lung, 3) postnatally TE expression decreases first in the outer medial smooth muscle cells, and 4) the pattern of expression in arteries differs from that in veins. In the $\mathbf{1 9}$ fetus, the signal for TE mRNA was higher in arteries than in veins. In the immediate postnatal period, the arterial signal declined, whereas the signal in veins increased. By postnatal d 21, the arterial TE signal per cell had significantly decreased to an intensity lower than that in veins. In the adult rat lung, no TE mRNA was detected by in situ hybridization. The reciprocal alterations in TE expression in pulmonary arteries and veins may suggest a response to the postnatal change in pulmonary blood pressure. We speculate that because all three cell types are potentially elastogenic they may all play a role in the remodeling that occurs after vascular injury. (Pediatr Res 31: 280-285, 1992)
\end{abstract}

\section{Abbreviations}

ISH, in situ hybridization

TE, tropoelastin

SSC, sodium chloride sodium citrate buffer

$\mathrm{RT}$, room temperature

PA, pulmonary artery

$P V$, pulmonary vein

TGF- $\beta$, transforming growth factor $-\beta$

The resilience of the vascular wall is attributed largely to its elastic laminae. Synthesis of the elastin pro-protein, TE, by vascular smooth muscle cells has been demonstrated in tissues (1-4) and isolated cells $(3,5,6)$. We have recently demonstrated the specificity of the TE complementary RNA probe and identified, by ISH, TE mRNA in endothelial cells of the rat preacinar PA in perinatal lung tissue (7). Although elastogenesis in pulmonary vascular cells is developmentally regulated (8) as in other tissues, the dramatic changes of pulmonary blood pressure and oxygenation at birth may be significant regulatory factors. Prosser et al. (9) have shown by ISH that there is increased TE mRNA

Received April 4, 1991; accepted November 4, 1991.

Correspondence and reprint requests: Akihiko Noguchi, M.D., Department of Pediatrics, Cardinal Glennon Children's Hospital, St. Louis University, School of Medicine, 1465 South Grand, St. Louis, MO 63104.

Supported in part by grants from the March of Dimes Birth Defects Foundation no. 1-1121 and American Lung Association of Eastern Missouri. in the medial smooth muscle cells of the hypoxia-induced pulmonary hypertensive calf compared with normotensive controls. With the physiologic postnatal drop in pulmonary arteriolar resistance, PA pressure decreases and PV pressure and flow rise concomitantly. To study the relative contribution of endothelial cells, smooth muscle cells, and adventitial fibroblasts to the formation of elastic laminae during normal perinatal pulmonary vascular adaptation and growth, we evaluated in perinatal rat pups TE mRNA distribution in the main PA, in preacinar and intraacinar arteries, and in postacinar and lobular PV. We found that TE expression decreases in the PA and increases in the PV postnatally and that endothelial cells, smooth muscle cells, and adventitial fibroblasts all show elastogenesis but have an individualized pattern of ontogenesis along the vascular tree.

\section{MATERIALS AND METHODS}

Timed pregnant Sprague-Dawley rats were purchased from Sasco (Indianapolis, IN). Gestational age was calculated from the first day when a vaginal plug was seen. At fetal d 19, animals were killed by $\mathrm{CO}_{2}$ and pentobarbital $(50 \mathrm{mg} / 100 \mathrm{~g}$ body wt), and the lungs from two to three fetuses were immersed in freshly made $4 \%$ paraformaldehyde in $\mathrm{PBS}, \mathrm{pH} 7.4$, at room temperature for 4-6 h. Lungs were then washed in PBS and serial 0.3$\mathrm{cm}$ thick sections parallel to the hilus were processed for paraffin embedding. Five- $\mu \mathrm{m}$ thick paraffin-embedded tissue sections were placed on clean microscopic slides prepared by the method of Hayashi et al. (10). The slides were dried in an oven at $37^{\circ} \mathrm{C}$ for $60 \mathrm{~min}$ and then used for ISH as described below. Lungs were similarly harvested from rat pups on postnatal $\mathrm{d} 4,11$, and 21 and from the adult nonpregnant female rat ( $250 \mathrm{~g}$ body $\mathrm{wt})$. This research protocol was approved by the Animal Care Committee of St. Louis University.

$c R N A$ probe. The 1.2-kb cDNA probe RE2 (11) was inserted in the pGEM $7 \mathrm{Z}+$ (Promega, Madison, WI), and the radiolabeled, single-stranded antisense and sense RNA probes were generated using ${ }^{35} \mathrm{~S}$-cytidine triphosphate and the riboprobe generation kit. The probes were then hydrolyzed in $0.1 \mathrm{M} \mathrm{Na}_{2} \mathrm{CO}_{3}$ buffer, $\mathrm{pH} 10.2$, for $30 \mathrm{~min}$ at $60^{\circ} \mathrm{C}$ to the median fragment size of $150-200$ bases determined by denaturing $5 \%$ acrylamide sizing gel electrophoresis (not shown). Estimated sp act was approximately $10^{9} \mathrm{cpm} / \mu \mathrm{g}$ for each probe. Specificity of the cRNA probe in the rat lung tissue has been demonstrated previously by Northern blot analysis and ISH (7).

Prehybridization treatment of tissue. Tissue sections on microscopic slides were deparaffinized and hydrated in PBS for 5 min

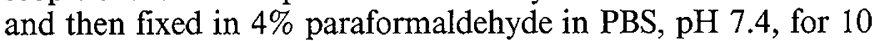
min. After a wash in PBS, slides were treated with $0.3 \%$ Triton $\mathrm{X}-100$ in PBS for $15 \mathrm{~min}$. A set of negative control sections were treated with RNase A $\left(50 \mathrm{~g} / \mathrm{mL}\right.$ in PBS) for $1 \mathrm{~h}$ at $37^{\circ} \mathrm{C}$. All of the sections were then treated with proteinase $\mathrm{K}(1 \mu \mathrm{g} / \mathrm{mL})$ in 0.1 Tris, pH 8.0, containing $150 \mathrm{~mm}$ EDTA at $37^{\circ} \mathrm{C}$ for $20 \mathrm{~min}$ and then immersed immediately in PBS containing $4 \%$ paraformaldehyde for $5 \mathrm{~min}$. This was followed by three washes with 
PBS for $5 \mathrm{~min}$ each. Slides were then treated with $0.1 \mathrm{M}$ triethanolamine buffer, $\mathrm{pH} 8.0$, for $5 \mathrm{~min}$ followed by freshly prepared $0.25 \%$ acetic anhydride for $10 \mathrm{~min}$ at room temperature. Samples were washed with $2 \times \mathrm{SSC}$ three times, $5 \mathrm{~min}$ each, dehydrated through graded ethanol (30 to $70 \%$ ), and air-dried.

ISH. Hybridization solution contained $50 \%$ formamide, $2 \times$ SSC, 20 mM Tris, pH 8.0, $1 \times$ Denhardt, 1 mM EDTA, 100 $\mathrm{mM}$ DTT, and $500 \mu \mathrm{g} / \mathrm{mL}$ yeast transfer RNA. Antisense or sense complementary RNA probe was added to the hybridization solution and heated to $68^{\circ} \mathrm{C}$ for $10 \mathrm{~min}$ to give $10^{6} \mathrm{cpm} / 30 \mu \mathrm{L} /$ slide. Thirty $\mu \mathrm{L}$ of heated hybridization mixture was placed on each section, which was covered by a piece of Parafilm and heated to $55^{\circ} \mathrm{C}$ overnight in a humidified chamber. The sections were then washed twice for 15 min each with $4 \times$ SSC containing $25 \mathrm{mM}$ mercaptoethanol, then with $0.5 \times$ SSC containing 25 $\mathrm{mM}$ mercaptoethanol for $5 \mathrm{~min}$, then once with $0.1 \times \mathrm{SSC}$ for $15 \mathrm{~min}$ at $60^{\circ} \mathrm{C}$, and then in the same buffer at RT for $5 \mathrm{~min}$. The slides were next treated with RNase A $(20 \mu \mathrm{g} / \mathrm{mL})$ in a buffer containing $0.5 \mathrm{M} \mathrm{NaCl}, 10 \mathrm{mM}$ Tris, $\mathrm{pH} 8.0$, and $1 \mathrm{mM}$ EDTA for $30 \mathrm{~min}$ at $30^{\circ} \mathrm{C}$ and rinsed in the same buffer alone for $30 \mathrm{~min}$ at $37^{\circ} \mathrm{C}$. The slides were washed for $30 \mathrm{~min}$ at RT with $2 \times \mathrm{SSC}$, with $0.1 \times \mathrm{SSC}$ once for $15 \mathrm{~min}$ at $60^{\circ} \mathrm{C}$, and then in the same buffer at RT for $30 \mathrm{~min}$. The sections were dehydrated through graded ethanol (30-70\%) and air-dried.

Autoradiography. In a dark room, NTB2 emulsion (Kodak Chemicals, Rochester, $\mathrm{NH}$ ) was melted at $42^{\circ} \mathrm{C}$ and diluted $1: 1$ with prewarmed water. The slides were dipped in the emulsion slowly, dried in a lightproof moist chamber for $45 \mathrm{~min}$ at RT, and transferred to a box containing silica gel to absorb the moisture. After $1 \mathrm{~h}$, the box was stored at $4^{\circ} \mathrm{C}$ for $1 \mathrm{wk}$. Development was done in solutions chilled to $15^{\circ} \mathrm{C}$ by dipping the slides in Kodak D19 developer (diluted 1:1 with deionized water) for $3 \mathrm{~min}$, in $1 \%$ acetic acid for $1 \mathrm{~min}$, in Kodak Rapidfix (diluted 1:3) for $5 \mathrm{~min}$, and in water three times, $10 \mathrm{~min}$ each. The slides were then air-dried for $30 \mathrm{~min}$ before counterstaining with hematoxylin. To standardize interpretation of results, sections of the same portion of d-11 lung tissue were included as the positive control in every batch of ISH experiments. The TE signal intensity was graded visually under the microscope compared with the control d-11 lung section, which was used as the reference. It was confirmed also in every batch of ISH experiments that d-11 lung parenchyma gave a strong signal at the septae as shown previously (7). Little interassay difference was noted in d-11 sections.

Materials. Rat elastin specific cDNA probe RE-2 was provided by Judith Foster, Ph.D. (Boston University). Radionucleotides were purchased from New England Nuclear (Boston, MA). Riboprobe generation kit, DNase, and other molecular biologyrelated enzymes were purchased from Promega. Restriction enzymes were from Bethesda Research Laboratories (Gaithersburg, MD). The other chemicals were purchased from Sigma Chemical Co. (St. Louis, MO).

\section{RESULTS}

Fetal $d$ 19. Probe specificity was assessed by comparing the antisense (complementary) ISH results with sense (noncomplementary) ISH results by use of bright- and dark-field illumination. In fetal d-19 rat lung, an intense autoradiographic signal was detected with the antisense probe in the main and hilar PA (Fig. $1 a$ and $c$ ). In contrast, no signal was detected with the sense probe (Fig. $1 b$ and $d$ ), and on dark-field illumination there was a homogeneous scattered background. No accumulation of silver grains was seen at the edge of tissue such as at endothelialluminal junctions with the sense probe (Fig. 1d). Intense label was most evident with bright-field illumination, whereas the dark-field illumination proved best for visualizing low levels of label. In addition to medial smooth muscle, the innermost (endothelial) layer of the arterial wall was heavily labeled with the antisense probe (Fig. $1 a$ and $c$ ), whereas with the sense probe no
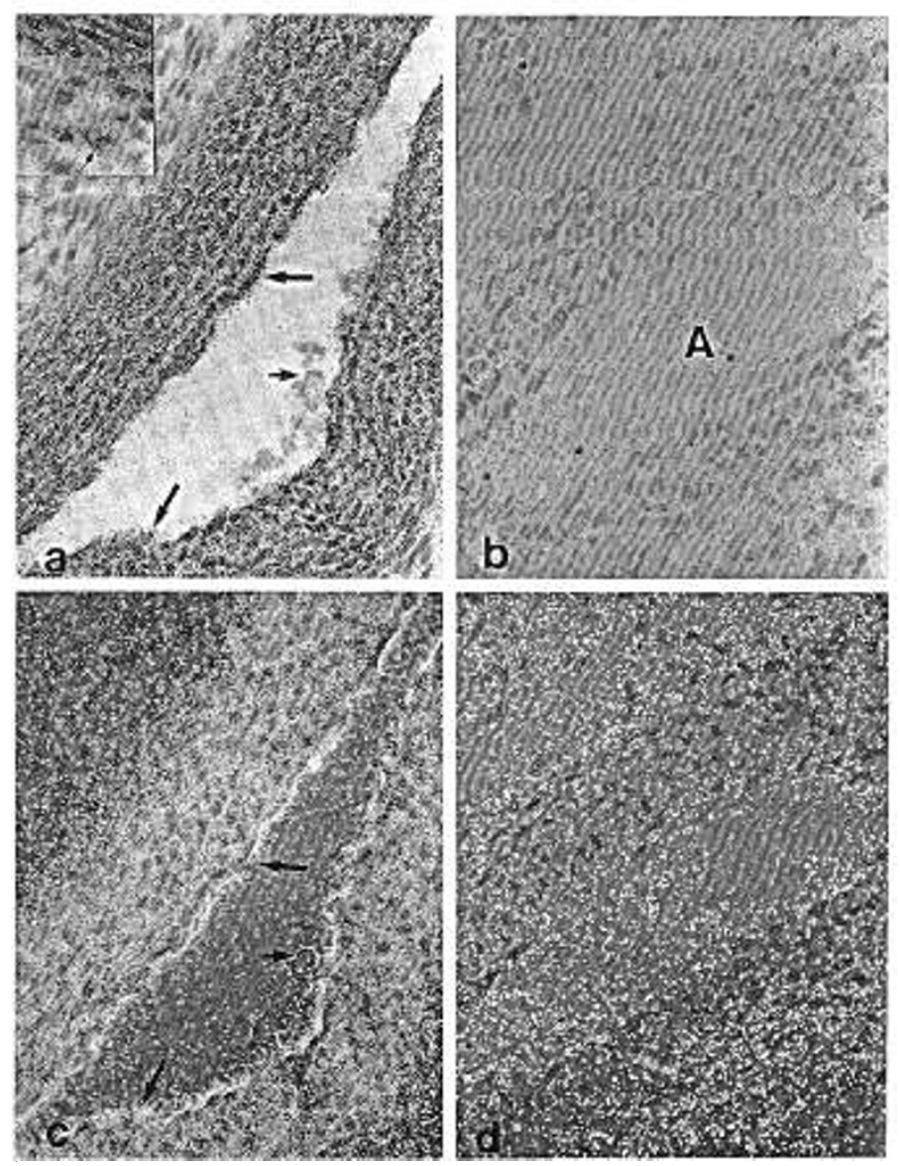

Fig. 1. Specificity of the cRNA probe for TE mRNA in d-19 fetal main PA. Representative bright- and dark-field views with the antisense probe study ( $a$ and $c$ ) and sense probe study ( $b$ and $d$ ) are shown. $a$ and $c$, The medial smooth muscle cell layer is densely labeled, showing black grain deposits in $a$ and white grains in $c$. Endothelial cells (long arrows) but not erythrocytes (short arrow) are labeled. Adventitia shows signal sporadically ( $a$, inset, small arrow). $b$ and $d$, There is no specific signal detected in both views. The dark-field view is more sensitive in detecting the grains, which demonstrated scattered background only. $A$ (part $b$ ), arterial lumen. All, original magnification $\times 400$.

label was seen (Fig. $1 b$ and $d$ ). Sporadic signals were detected in adventitial fibroblasts of main PA and preacinar arteries. In cross-sections, the signal intensity was uniform throughout the thickness of the media (Figs. $1 a$ and $c$ and 2). Signal intensity appeared greater in larger arteries than in smaller arteries along the length of the preacinar arterial tree (Fig. $2 b$ ). This was also true in the lung sections of subsequent ages. Intraacinar arteries were not identified at this stage. In the PV system, signal intensity was generally weak; it was lower than that in the PA and present only in smooth muscle cells and endothelial cells (Fig. 2c). In the parenchyma, there was a weak signal confined to the septal tips, but absent in the majority of interstitial cells (Fig. $2 b$ ).

Postnatal $d 4$. In the PA system, TE signal was present in endothelial cells, smooth muscle cells, and adventitial fibroblasts in the main pulmonary, hilar, and distal preacinar arteries (Fig. $3 a$ and $b$ ). TE message was recognized also in intraacinar arteries at this stage. The signal in the medial smooth muscle layer, however, was not uniformly intense as seen at gestation d 19, but instead was lower in the outer layer of the media (Fig. 3d). This signal distribution was better visualized with bright-field rather than with dark-field illumination (Fig. $3 d$ ). The endothelial cells were consistently positive (Fig. $3 c$ ), but adventitial fibroblasts were only sporadically positive (Fig. $3 d$ ). In the PV system, the signal intensity in endothelial and smooth muscle cells increased from d 19 fetal stage relative to the arterial signal, 

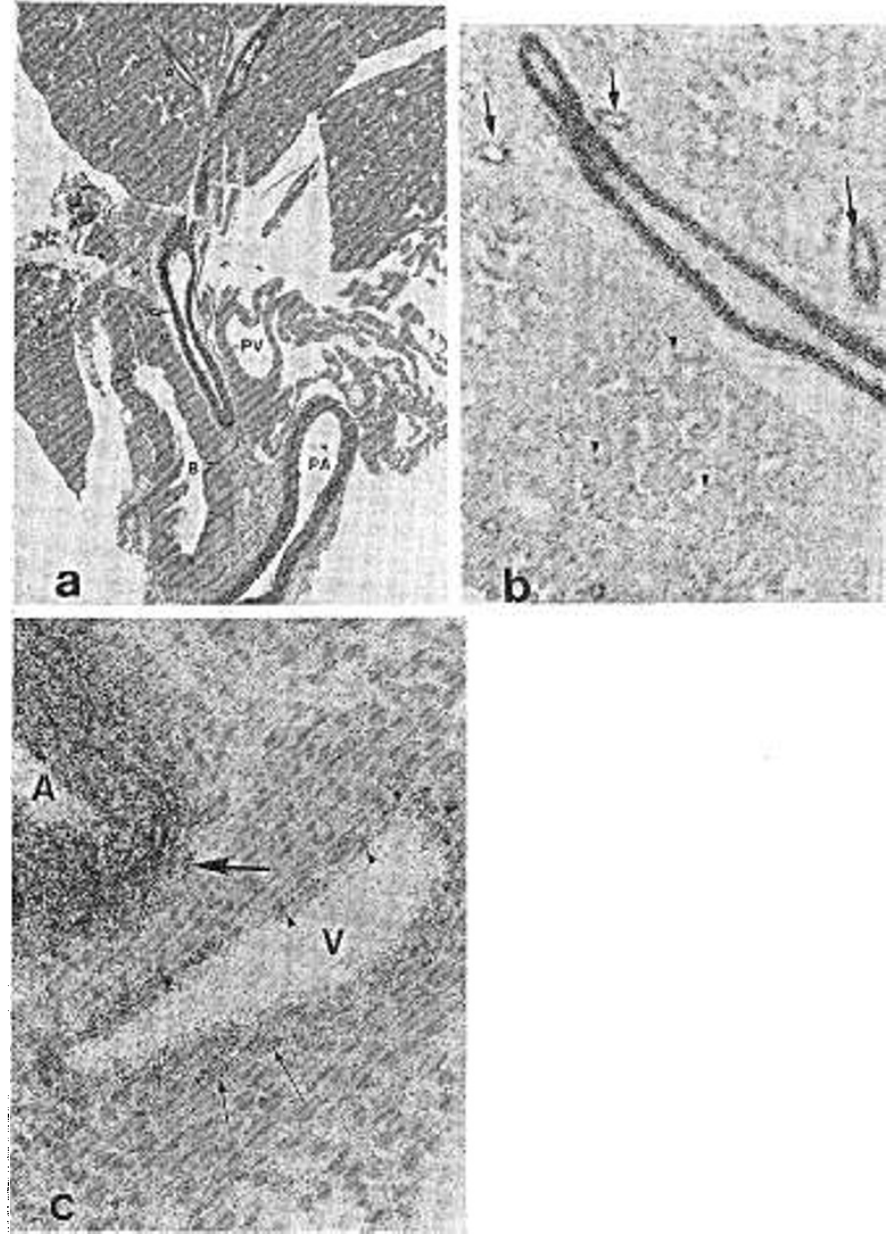

Fig. 2. ISH for TE mRNA on $\mathrm{d}-19$ fetal rat lung. $a, \mathrm{PA}, \mathrm{PV}$, and bronchus $(B)$ of hilar region and preacinar arteries $(A)$ are shown. Strong TE message in PA but not in PV. Original magnification $\times 40 . b$, Longitudinal section of PA. There is a longitudinal gradient in the intensity of signal, which is lowest in the most distal preacinar arteries (arrows). In the lung parenchyma, signal is confined to the tips of alveolar septae (arrowheads). Original magnification $\times 100 . c$, In the lobar vein ( $V$ ), signal is present in the endothelial cells (arrowheads) and smooth muscle cells (arrows), but the intensity appears lower than that of the lobar artery $(A)$. Adventitial cells are sporadically labeled (large arrow) in the artery, but not seen in the vein. Original magnification $\times 400$.

and a weak signal was seen in adventitial cells (Fig. $3 b$ and $d$ ). The signal in the lung parenchyma was present at the septal tips and increased compared with gestation $\mathrm{d} 19$ because of the development of secondary septae at this time.

Postnatal $d$ 11. In the PA trunk, the aorta, and the ductus arteriosus, the signal pattern was patchy, and the intensity was lower in the PA than in the aorta (Fig. 4a, inset). In the main PA, signal in the medial layer was not uniformly intense (Fig. $4 a$ and c). In general, signal in the inner media was greater than in the outer media, and in some areas of media little or no signal was observed (Fig. $4 b$ and $d$ ). Signal was consistently present in endothelial cells (Fig. 4a-d) and sporadically present in adventitial fibroblasts (Fig. $4 b$ and $d$ ). In postacinar intralobular veins, the signal was present in endothelial cells, smooth muscle cells, and adventitial cells, similar to postnatal d 4 (not shown). In the parenchyma, the signal intensity and the number of septal cells expressing the signal were increased and were higher at this age (Fig. 4e) than at any other age, reflecting active alveolarization of the lung. Signal was present at the septal tips and in alveolar walls.

Postnatal $d 21$. In the main PA, the signal was present in smooth muscle cells, endothelial cells, and adventitial fibroblasts
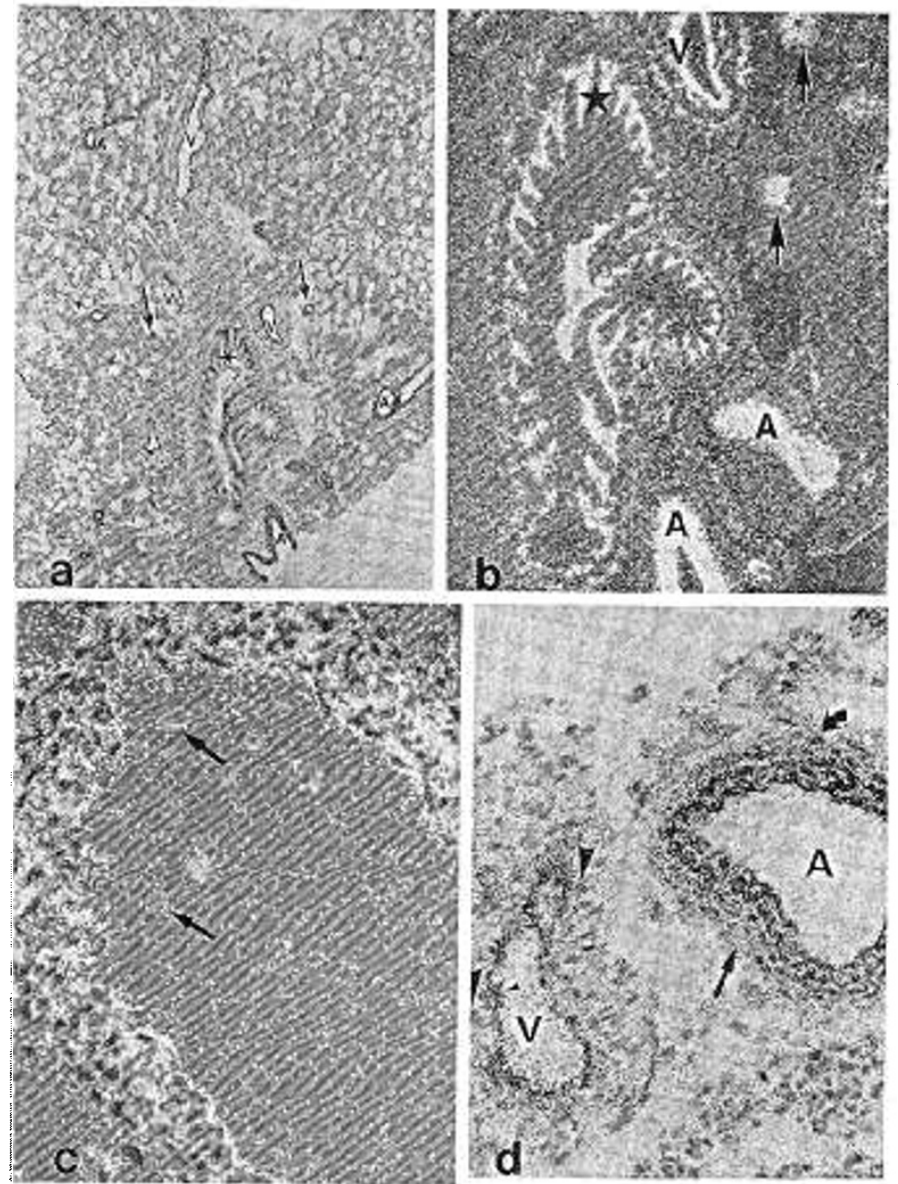

Fig. 3. ISH for TE mRNA on d-4 postnatal rat lung section. $a$, The signal is seen clearly in the arteries $(A)$, vein $(V)$, and bronchial cartilage $\left.{ }^{*}\right)$. Signal is present even in the intraacinar arteries (arrows). Still, the message in the parenchyma is weak. Original magnification $\times 40$. $b$, Magnification of a portion of photograph $a$ in a dark field. Postacinar vein $(V)$ shows adluminal and adventitial labeling. $\star$, Bronchial cartilage. Arrows indicate intraacinar arteries. Original magnification $\times 100$. c, Dark-field view of preacinar artery. Endothelial cells of the arterial wall are labeled compared with background grain intensity around erythrocytes (arrows). Original magnification $\times 400$. $d$, Preacinar artery $(A)$ and vein $(V)$. Signal in the outer layers of the medial smooth muscle cells is decreased (straight arrow). In the vein, the signal intensity in endothelial cells (small arrowhead) and smooth muscle cells (big arrowhead) is comparable to that in artery. There is a weak signal in the adventitia. Original magnification $\times 400$.

but was weaker than in the previous stages (Fig. $5 a$ and $b$ ). In the preacinar PA, there was a significant decrease in the TE mRNA in medial smooth muscle throughout compared with the previous stages (Fig. $5 c$ ). In the bronchial arteries, the signal intensity was consistently higher than it was in the PA at this stage (Fig. $5 c$ ). In preacinar arteries, the signal was present in the endothelium and the smooth muscle cells (Fig. $6 a$ and $c$ ) and weakly present in adventitial fibroblasts (not shown). In the postacinar and hilar PV, the signal was confined to endothelial cells and smooth muscle cells (Fig. $6 b$ and $d$ ) and hardly detected in the adventitia (not shown). The intensity of the signal in venous smooth muscle and endothelial cells was higher than that in arteries (Fig. $6 a$ versus $b$ and $c$ versus $d$ ). In the lung parenchyma, the TE signal was decreased significantly from that at 11 d of age.

Adult. There was no detectable message in arteries, veins, or parenchyma in the adult rat lung (Fig. 7).

\section{DISCUSSION}

Elastin has one of the slowest turnover rates among the known proteins (12), and immunohistochemical staining of the extra- 

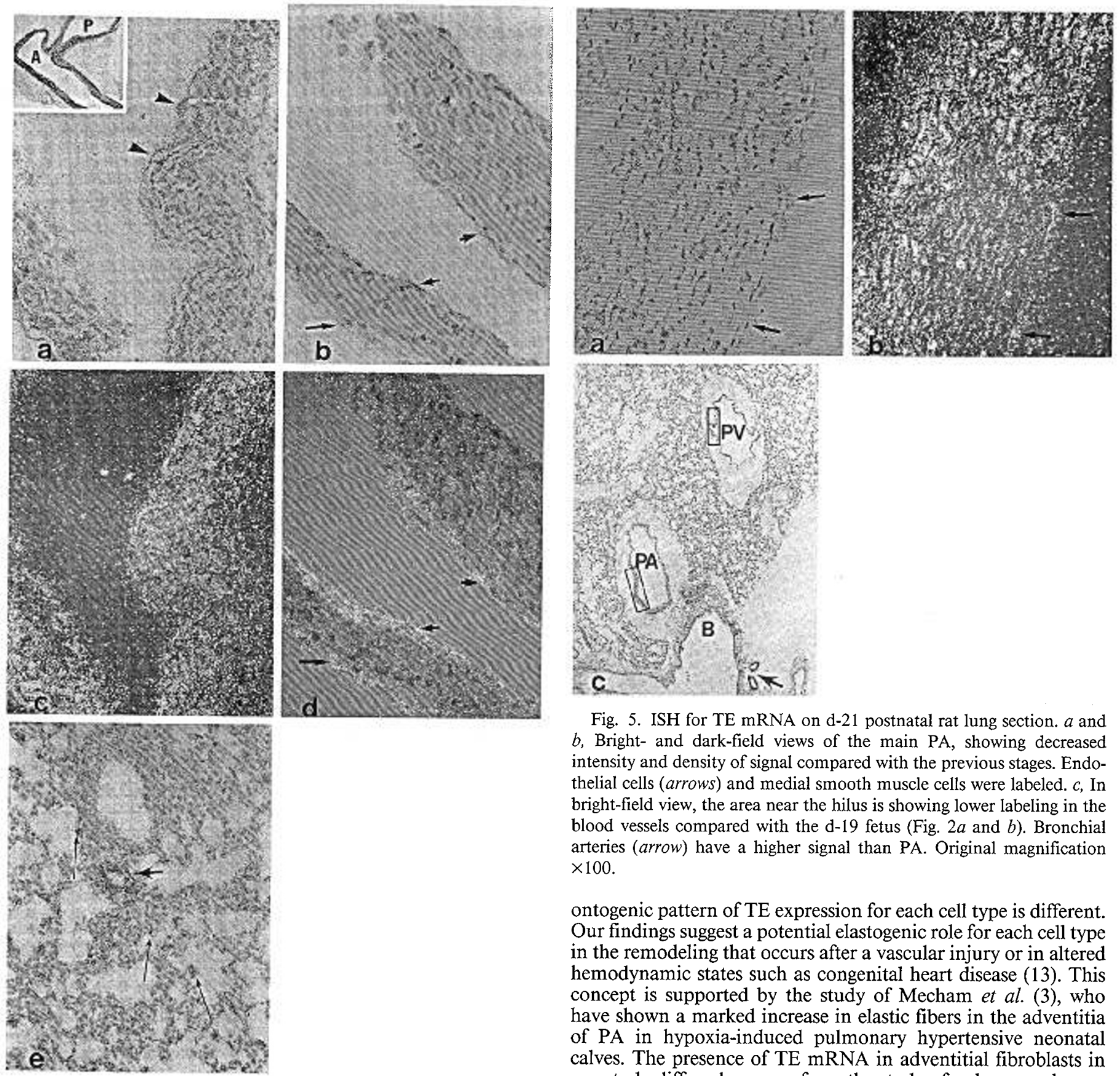

Fig. 5. ISH for TE mRNA on d-21 postnatal rat lung section. $a$ and $b$, Bright- and dark-field views of the main PA, showing decreased intensity and density of signal compared with the previous stages. Endothelial cells (arrows) and medial smooth muscle cells were labeled. $c$, In bright-field view, the area near the hilus is showing lower labeling in the blood vessels compared with the d-19 fetus (Fig. $2 a$ and $b$ ). Bronchial arteries (arrow) have a higher signal than PA. Original magnification $\times 100$.

ontogenic pattern of TE expression for each cell type is different. Our findings suggest a potential elastogenic role for each cell type in the remodeling that occurs after a vascular injury or in altered hemodynamic states such as congenital heart disease (13). This concept is supported by the study of Mecham et al. (3), who have shown a marked increase in elastic fibers in the adventitia of PA in hypoxia-induced pulmonary hypertensive neonatal calves. The presence of TE mRNA in adventitial fibroblasts in our study differs, however, from the study of pulmonary hypertensive and control neonatal calves, in whom the TE signal was reportedly absent (9). The lack of TE mRNA by ISH in adventitial cells of the pulmonary hypertensive calf model is likely related to the age at which the calf was killed and perhaps could have been detected if examined at an earlier age. Our sequential examinations have shown that the period of TE synthesis by PA adventitial cells was shortest among the three cell types and limited to a fraction of the cell population. The difference in the ontogenic pattern among the cell types suggests an intrinsic factor possibly regulated by a specific program for elastogenesis in each cell type. There was a postnatal decrease in the signal in the PA and an increase in the PV. The artery-vein difference shown in the present study points to an extrinsic regulatory factor as well. Accompanying the physiologic changes at birth, there is increased oxygenation and pulmonary blood flow, a decrease in the PA pressure, and an increase in the PV pressure. We speculate that the changes in the blood pressure influence TE expression in the vascular wall. It is unlikely that the postnatal increase in blood oxygenation and/or pulmonary blood flow are responsible for

cellular protein does not reflect ongoing TE synthesis. Use of ISH in fetal, postnatal, and adult rat lungs allowed us to identify elastogenic cells and sequentially examine TE expression in the pulmonary vasculature. We found that the three cellular components of the vascular wall, endothelial cells, medial smooth muscle cells, and adventitial fibroblasts, all participate in the normal development of elastic laminae in vivo, although the 

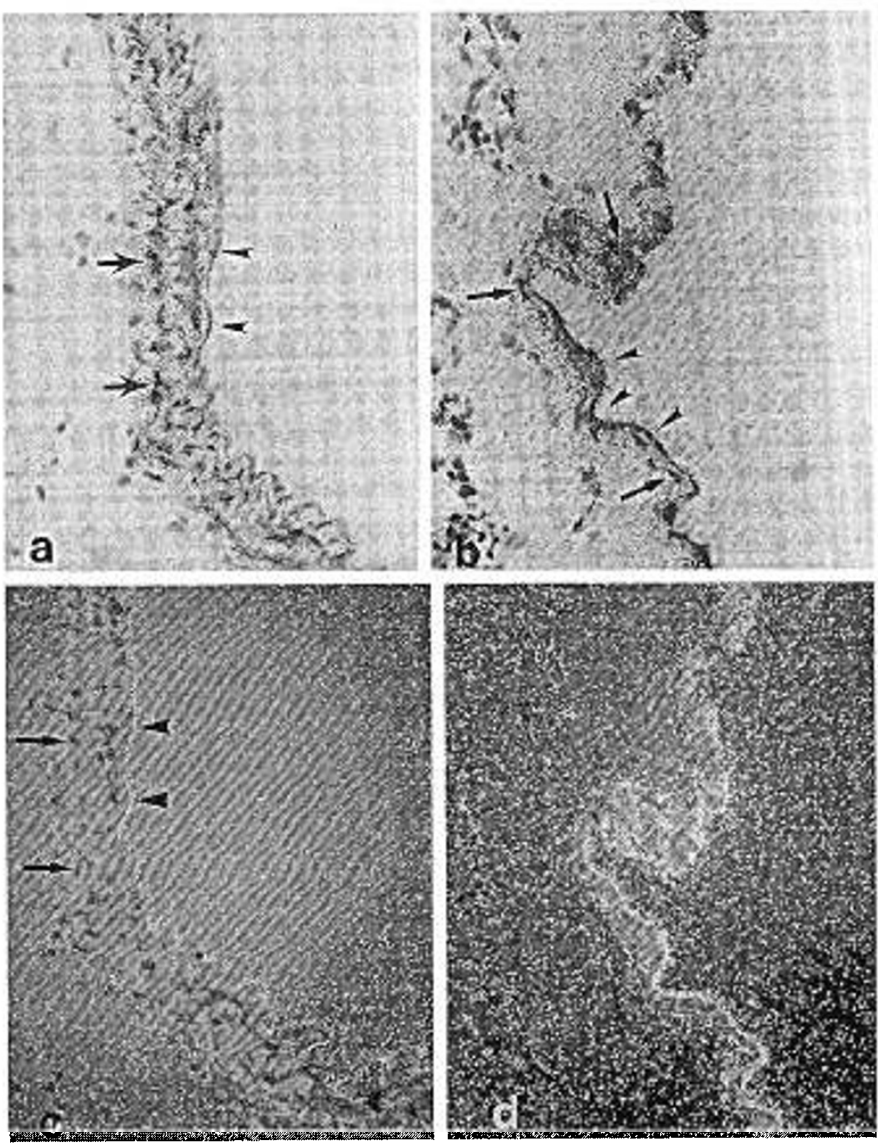

Fig. 6. ISH for TE mRNA on d-21 postnatal rat lung. Magnification of respective PA ( $a$ and $c$ ) and PV ( $b$ and $d)$ in Fig. $5 c$ (framed areas) are shown. In bright- and dark-field views, the signal in endothelial cells (arrowheads) and smooth muscle cells (arrows) in PA ( $a$ and $c$ ) is lower than in $\mathrm{PV}(b$ and $d)$. Original magnification $\times 400$.

altering TE expression, inasmuch as they would have changed the signal in PA and PV in the same fashion. Our results correlate with the findings of Parks et al. (14), who showed that the PV of the hypoxia-induced pulmonary hypertensive calf had decreased TE mRNA in contrast to the normotensive control. They speculated that the decreased pressure and flow in the PV in contrast to the PA contributed to the decreased TE message. We believe that the rising PV pressure in the neonate stimulates elastic fiber formation. The stimulatory effect of blood pressure on TE expression is further substantiated by our observation that the aorta and the bronchial arteries postnatally showed a higher signal than the main PA (Fig. 4a) and the lobar PA (Fig. 5c), suggesting more active elastogenesis in systemic arteries rather than in PA, leading to a greater ultimate elastin content. In the rabbit, Leung et al. (15) have shown that the aorta and the PA trunk at birth contain equal amounts of elastin, but by $2 \mathrm{mo}$ elastin in the ascending aorta is three times greater than in the main PA trunk (15). In that study, estimated wall tension was unchanged postnatally in the PA as opposed to a 10 -fold increase in the aorta, proposing that the development of collagen and elastin fibrils in the two great vessels correlates with tangential tension (15). However, our ISH result of declining PA TE synthesis soon after birth suggests that TE synthetic activity in the PA is more directly related to the blood pressure per se or pulse pressure during the perinatal period. We confirmed our previous observation that the elastogenesis by outer medial smooth muscle cells declines more rapidly compared with the inner layer after birth (7). The findings suggest that the outer medial smooth muscle cells are more sensitive to the drop in the blood pressure than the inner media. How blood pressure changes alter TE expression is a matter for speculation and could
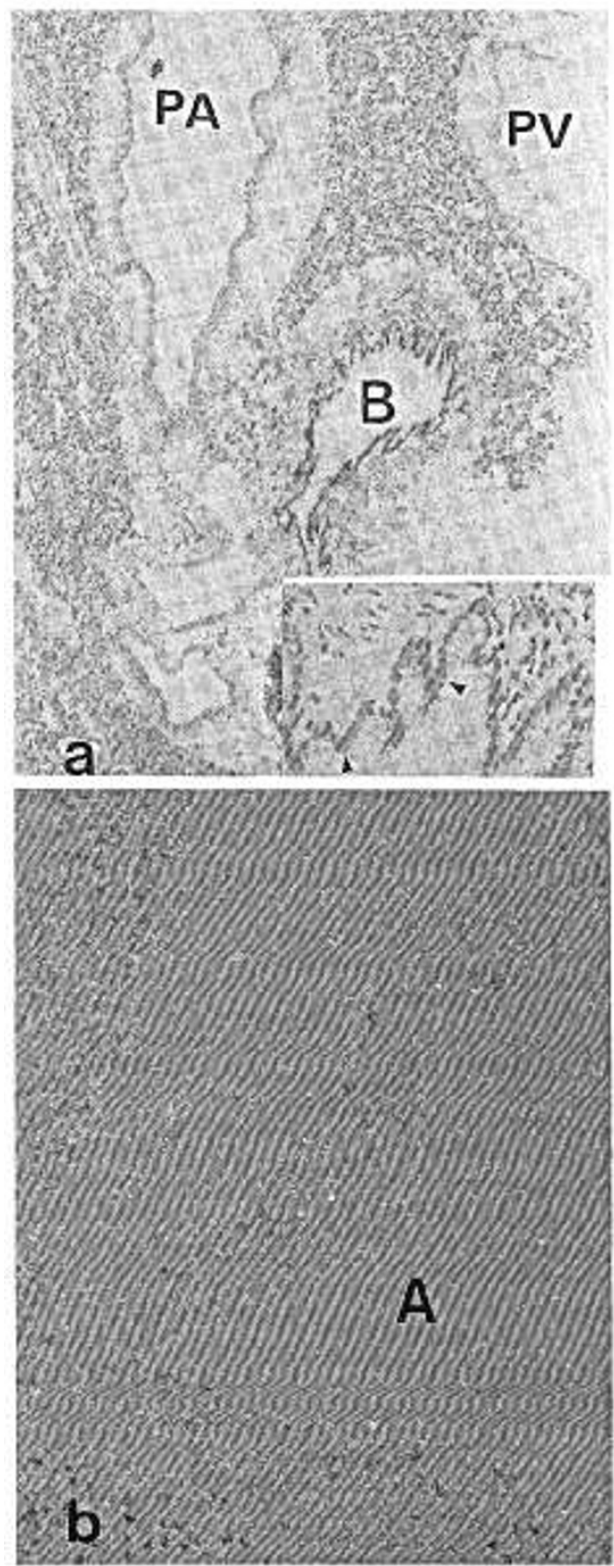

Fig. 7. ISH for TE mRNA in adult rat lung section. $a$, PA, PV, and bronchus $(B)$ at hilus and pulmonary parenchyma are all negative for the message. Original magnification $\times 100$. The darker staining of the bronchiolar wall is the epithelial nuclear staining by hematoxylin as shown in higher magnification $(\times 400)$ in the inset (arrowheads). $b$, Higher magnification of the PA wall in a dark-field view showing no labeling. $A$, arterial lumen. Original magnification $\times 400$.

be multifactorial. One possibility is that there is an autocrine or paracrine mediator(s) secreted locally. A smooth muscle cellderived TE stimulating factor has been demonstrated in response to pulmonary hypertension (3). The role of this factor in the physiologic perinatal adaptation and growth of the pulmonary vasculature is not known. TGF- $\beta$ is another candidate because it increases in the vascular wall in response to hypertension (16) and could in turn increase TE synthesis (17). However, Botney et al. (18) recently reported in a preliminary form that the normal rise in TGF- $\beta$ mRNA was not seen in the PA of the pulmonary hypertensive calf. Studying the expression of TE and TGF- $\beta$ simultaneously in the normal perinatal pulmonary vasculature would further clarify this issue. In our study, there appears to be a gradient of TE expression along the length of the arterial tree. However, it was not clear if it is indeed related to the gradient of signal intensity per cell or is a reflection of varying cell density. 
One additional finding of interest was the pattern of TE signal decline in the medial smooth muscle cells of the PA trunk. The signal decreased postnatally in a patchy pattern without regularity as opposed to the more distal arteries, where the signal declined first in the outer media. It is not clear if this topographical pattern is related to environmental factors such as the local pressure changes or to an intrinsic heterogeneity of cells in this section of the vascular wall.

Acknowledgment. The authors thank William J. Kennan, M.D., for reviewing the manuscript and Sara Heyman for technical assistance.

\section{REFERENCES}

1. Eichner R, Rosenbloom J 1979 Collagen and elastin synthesis in the developing chick aorta. Arch Biochem Biophys 198:414-423

2. Foster J, Rich CB, Florini JR 1987 Insulin-like growth factor I, somatomedin $\mathrm{C}$, induces the synthesis of tropoelastin in aortic tissue. Coll Relat Res 7:161169

3. Mecham RP, Whitehouse LA, Wrenn DS, Parks WC, Griffin GL, Senior RM, Crouch EC, Stenmark KR, Voelkel NF 1987 Smooth muscle mediated connective tissue remodeling in pulmonary hypertension. Science 237:423426

4. Pioiani GJ, Tozzi CA, Yohn SE, Pierce RA, Belsky SA, Berg RA, Yu SY, Deak SB, Riley DJ 1990 Collagen and elastin metabolism in hypertensive pulmonary arteries of rats. Circ Res 66:968-978

5. Saunders NA, Grant ME 1984 Elastin biosynthesis in chick embryo arteries. Biochem J 221:393-400

6. Chipman SD, Faris B, Barone LM, Pratt CA, Franzblau C 1985 Processing of soluble elastin in cultured neonatal rat smooth muscle cells. J Biol Chem $260: 12780-12785$
7. Noguchi A, Samaha H 1991 Developmental changes in tropoelastin gene expression in the rat lung studied by in-situ hybridization. Am J Respir Cell Mol Biol 5:571-578

8. Davidson JM, Hill KE, Alford JL 1986 Developmental changes in collagen and elastin biosynthesis in the porcine aorta. Dev Biol 118:103-111

9. Prosser IW, Stenmark KR, Suthar M, Crouch EC, Mecham RP, Parks WC 1989 Regional heterogeneity of elastin and collagen gene expression in intralobar arteries in response to hypoxic pulmonary hypertension as demonstrated by in situ hybridization. Am J Pathol 135:1073-1088

10. Hayashi M, Ninomiya Y, Parsons J, Hayashi K, Olsen BR, Trelsted RL 1986 Differential localization of mRNAs of collagen types I and II in chick fibroblasts, chondrocytes, and corneal cells by in situ hybridization using cDNA probes. J Cell Biol 102:2302-2309

11. Rich CB, Foster JA 1989 Characterization of rat heart tropoelastin. Arch Biochem Biophys 268:551-558

12. Rucker RB, Dubick MA 1984 Elastin metabolism and chemistry: potential roles in lung development and structure. Environ Health Perspect 55:179184

13. Rabinovitch M, Bothwell T, Hayakawa BN, Williams WG, Trusler GA, Rowe RD, Olley PM, Cutz E 1986 Pulmonary artery endothelial abnormalities in patients with congenital heart defects and pulmonary hypertension. A correlation of light and scanning electron in microscopy and transmission electron microscopy. Lab Invest 55:632-653

14. Parks WC, Mecham RP, Crouch EC, Orton EC, Stenmark KR 1989 Responses of lobar vessels to hypoxic pulmonary hypertension. Am Rev Respir Dis 140:1455-1457

15. Leung DYM, Glagov S, Mathews MB 1977 Elastin and collagen accumulation in rabbit ascending aorta and pulmonary trunk during postnatal growth. Circ Res 41:316-323

16. Sarzani R, Brecher P, Chobanian AV 1989 Growth factors in aorta of normotensive and hypertensive rats. J Clin Invest 83:1404-1408

17. Liu J, Davidson JM 1988 The elastogenic effect of recombinant transforming growth factor-beta on porcine aortic smooth muscle cells. Biochem Biophys Res Commun 154:895-901

18. Botney M, Parks W, Stenmark K, Mecham P 1991 Determination of transforming growth factor- $\beta$ mRNA levels in pulmonary arteries from normal and hypoxic calves. Chest 99 (suppl):42S 